\title{
Hubungan Antara Perhatian Orang Tua Dengan Perkembangan Karakter Tanggungjawab Belajar Anak Usia 7-8 Tahun Selama Masa Pandemi Di RW 12 Kelurahan Pasie Nan Tigo
}

\author{
Thania Diyelsa Aveta Deni , Ismaniar \\ Universitas Negeri Padang \\ * e-mail: thaniadiyelsa96@gmail.com ismaniar.js.pls@fip.unp.ac.id
}

\begin{abstract}
This research was motivated by the low development of the character of learning responsibility for children aged 7-8 years during the pandemic in $R W 12$, Pasie Nan Tigo Village. It is suspected that one of the reasons is the lack of parental attention to early childhood. This study aims to: describe parental attention to early childhood, describe the development of the learning responsibility character of children aged 7-8 years, see the relationship between parental attention and the development of the learning responsibility character of children aged 7-8 years during the pandemic in $R W$ 12, Pasie Nan Village. Tigo. This research is a correlational quantitative type. The population of this study were all parents of early childhood in $R W$ 12, Pasie Nan Tigo Village and the sample was taken by random sampling technique. Data collection techniques using a questionnaire or questionnaire. The research data were then analyzed using descriptive formulas and Range Order correlation. The results of this study indicate that parental attention to early childhood is categorized as low, the development of the learning responsibility character of children aged 7-8 years during the pandemic period is categorized as low, and there is a significant relationship between parental attention and the development of the learning responsibility character of children aged 7-8 years during the pandemic. during the pandemic at RW 12, Pasie Nan Tigo Village. The research suggestion is that it is hoped that parents can increase their attention to their children, this is because the maximum attention given by parents will be able to make children grow and develop optimally in accordance with the values and norms that apply in society.
\end{abstract}

Keywords: perhatian orang tua, karakter tanggungjawab belajar, pendidikan keluarga

\section{PENDAHULUAN}

Pendidikan ialah aktivitas tindakan yang bertujuan untuk menambah keterampilan, pengetahuan dan pembiasaan yang dikembangkan dari masa ke masa berikutnya. Salah satu bagian yang terpenting didalam kehidupan manusia ialah pendidikan. Pendidikan dapat mengelompokkan antara manusia dengan makhluk lainnya. Manusia belajar dengan beberapa rangkaian proses yang harus dilewati sehingga diharapkan mampu mengarah untuk berkembang gunu agar dapat kearah yang lebih baik serta mendapat pengetahuan yang luas. 
Pendidikan nonformal berperan utama dalam meningaktkan dan membina kualitas sumber daya masyarakat, keluarga dan lembaga. Pendidikan nonformal memiliki jenis-jenis pendidikan salah satunya ialah pendidikan anak usia dini (PAUD). PAUD yaitu wujud pendidikan nonformal dalam memberikan patokan agar mengembangkan kemampuan anak (Latifah; Ismaniar; Sunarti, 2018).

Berdasarkan Undang-undang No. 20 Tahun 2003 tentang sistem Pendidikan Nasional Pasal 1 nomor 14, menyampaikan bahwa PAUD ialah suatu usaha pembekalan yang difokuskan bagi anak usia dini hingga usia enam tahun yang dilaksanakan dengan proses memberi stimulus pendidikan guna menunjang perkembangan jasmani maupun rohaninya supaya ia kemudian mempunyai kesedian dalam menempuh pendidikan (Aziz, 2016). Sedangkan batasan anak usia dini diterangkan NAEYC (National Assocoation for The Education of Young Children), ialah anak yang usianya direntang umur 0-8 tahun, yang meliputi berbagai program pendidikan diantaranya yaitu penitipan anak pada keluarga, taman penitipan anak, pendidikan prasekolah negeri maupun swasta. Sekolah menjadi tempat berlangsungnya proses pendidikan formal, di sekolah semua anak memperoleh pendidikan formal dari guru mereka yang seharusnya. Namun sejak pertengahan bulan maret 2020 Negara Indonesia mendapatkan sebuah musibah penyebaran virus dari Negara Tiongkok, dimana virus ini dikenal dengan istilah lain yaitu COVID-19.

Virus ini menyebar dan menjangkiti warga Negara Indonesia lainya tak terkecuali kotakota yang berada di Pulau Sumatera. Salah satu kota yang terjangkit virus ini adalah Kota Padang, Akibatnya Pemerintah Kota Padang memberlakukan Social Distancing dan Physical Distancing, Hal ini bertujuan supaya masyarakat mengurangi aktivitas maupun interaksi sosialnya dengan berada dirumah. Dampak dari pelaksanaan sosial distancing dan physical distancing ini tentu mengganggu hubungan sosial yang tengah berlangsung di masyarakat dan mempengaruhi semu aktivitas yang dilaksanakan masyarakat sehari-hari tak terkecuali proses pendidikan. Proses pembelajaran dan pendidikan diminta oleh pemerintah untuk dipindahkan kerumah dengan sistem online.

Pembelajaran berbasis online artinya semua kegiatan pembelajaran siswa dari sekolah akan dilaksanakan melalui sistem online yang dilaksanakan seluruh anak di rumah mereka masing-masing. Pembelajaran ini diperuntukan untuk semua satuan pendidikan di Kota Padang dimulai dari pendidikan anak usia dini hingga kepada universitas dan pendidikan sejajar lainnya. Pembelajaran dari rumah adalah proses pengajaran yang tidak dibarengi dengan adanya aktivitas tatap muka secara langsung antar pendidik dengan anak didik, melainkan aktivitas tersebut dilangsungkan secara online (Maulani \& Bartin, 2021).

Pembelajaran dengan sistem online ini dilaksanakan dengan menggunakan beberapa aplikasi online seperti, Whatssapp, Zoom, Google Classroom, Geschool dan beberapa aplikasi serupa lainya. Dengan demikian peran keluarga sangat penting untuk proses pembelajaran dari rumah ini. Dalam keluarga, anak akan mendapatkan bimbingan guna membina karakter dan wataknya. Anak akan mendapatkan dasar-dasar pendidikan melalui orang tuanya. Oleh karenannya orang tua diharuskan untuk menanam nilai maupun norma yang berlaku dalam masyarakat kepada diri anak supaya ia bisa terarah secara baik, orang tua juga diharuskan bisa membangun hubungan yang harmonis dengan anak (Ismaniar, Jamaris, \& Wisroni, 2018).

Hubungan yang harmonis inilah yang kemudian dapat membentuk kondusifnya aktivitas belajar. Sebagaikan diungkapkan dalam UU No. 20 tahun 2003 Tentang Sisdiknas Pasal 7 ayat 1 yakni orang tua berhak menentukan pendidikan serta mendapat informasi terkait perkembangan pendidikan anaknya. Perhatian orang tua salah satu bentuk simpati, kasih sayang, serta bentuk kepedulian orang tua akan keberadaan anaknya. Kemudian daripada itu, orang tua juga membimbing aktivitas belajar anaknya melalui, penyediaan sarana dan prasarana pembelajaran sebagai pendukung proses pembelajaran bagi anak. Bentuk lain dari kepedulian orang tua terhadap anaknya adalah memberikan fasilitas dan apresiasi pada anak dalam proses belajar. Menurut Pujiningrum, Siswanto, \& Sukamto (2021), perhatian ialah pemusatan ataupun kosentrasi serta semua kegiatan seseorang yang ditujukan pada seuatu hal ataupun sekumpulan objek. Perhatian orang tua ialah sebuah kegiatan yang tertuju pada sesuatu dalam perihal ini yakni 
kegiatan anak sewaktu belajar yang dilaksanakan oleh orangtuanya. Orangtua berarti ayah, ibu, ataupun wali yang bertanggungjawab atas pendidikan anak.

Menurut Agustiningrum \& Rohidi (2020), perilaku bertanggungjawab ialah tindakan yang menunjukkan sikap mandiri. Bisa disimpulkan bahwasanya tanggungjawab ialah kesadaran manusia akan perilaku ataupun perbuatanya yang disengaja ataupun yang tidak. Dalam melakukan peningkatan tanggungjawab anak dilaksanakan melalui memberi kegiatan berupa tugas serta kepercayaan bahwasanya anak dapat melaksanakannya dengan baik. Setiap orang memiliki tanggungjawab dari usia dini hingga dewasa. Disegala tingkatan usia mempunyai tanggungjawab yang tidak sama. Tanggungjawab untuk usia dini cenderung sederhana dari pada dengan tanggungjawab orang dewasa. Namun, tanggungjawab pada dasarnya tidak melihat dari batasan umur, karena setiap tindakan yang dilakukan pasti terdapat sesuatu yang mesti dipertanggungjawabkan. Dari tindakan-tindakan tersebut maka setiap individu mesti bertanggungjawab kepada diri sendiri, keluarga, tuhan, negara, serta masyarakat. Secara umum dari karakteristik tersebut telah mulai tampak dari anak umur 7-8 tahun, namun pada kenyataan di lapangan ditemukan tidak semua cocok dengan pendapat para ahli tersebut.

Menurut Lickona (2016), karakter tanggungjawab merupakan sebuah bentuk hukum moral alamiah secara naluri batin yang menjadi pondasi didalam susunan agenda moral. Tanggungjawab pada anak adalah awal dari pembentukan karakter yang berdaya guna untuk dikembangkan, sebab anak yang terlatih dengan sikap tanggungjawab akan bertumbuh menjadi individu yang mandiri dan disiplin dalam semua hal yang dilakukan. Pemberian tingkah laku ini dimulai semenjak dini turut mengarahkan bentuk sikap tanggungjawab pada usia yang akan datang. Karakter ini mesti ditanam serta dibimbing semasa pertumbuhan sebab setiap jangka kehidupan mempunyai tugas perkembangan masing-masing. Bila tugas tersebut tidak tuntas, maka akan menyebabkan perkembangan pada tahap selanjutnya menjadi terhalang.

Menurut Nuraeni (2018), menyatakan anak mulai belajar tanggung jawab ketika anak sudah beranjak usia dua tahun. Anak belajar untuk mulai merapikan permainan, meletakkan barang pada tempatnya, mulai membantu tugas orangtua dan anak tempat waktu dalam suatu kegiatan. Tugas perkembangan karakter tanggung jawab anak usia 7-8 tahun, diungkapkan Monalisa \& Ismaniar (2020), mempunyai karakter tanggung jawab sebagai proses pembelajaran, yakni: 1) Merapikan mainan ataupun peralatan yang sudah digunakan, 2) Menjaga barang miliknya ataupun miliki orang lain, 3) Meminta maaf dan mengakui kesalahan, 4) Merawat barang milik sendiri.

Fenomena yang terlihat dari hasil observasi peneliti pada tanggal 10 Agustus 2021 dari rumah ke rumah warga yang mempunyai anak usia 7-8 tahun yang mengalami masalah pada karakter tanggungjawab anak. Wawancara yang peneliti lakukan dengan melibatkan 20 orang tua. Untuk lebih jelas hasil wawancara atau observasi tersebut sebagai berikut:

Tabel 1.

Hasil Observasi Karakter Tanggungjawab Belajar Anak Usia 7-8 Tahun di RW 12 Pasie Nan Tigo

\begin{tabular}{|c|c|c|c|c|c|c|c|c|c|c|}
\hline No & Indikator & \multicolumn{6}{|c|}{ Aspek yang dinilai } & \multirow{2}{*}{ N } \\
\cline { 4 - 8 } & $\mathbf{B B}$ & $\mathbf{\%}$ & $\mathbf{M B}$ & $\mathbf{\%}$ & $\mathbf{C B}$ & $\mathbf{\%}$ & $\mathbf{B S}$ & $\mathbf{\%}$ & \\
\hline 1 & $\begin{array}{c}\text { Anak mampu merapikan peralatan } \\
\text { atau mainan yang telah } \\
\text { digunakan. }\end{array}$ & 8 & 40 & 10 & 50 & 2 & 10 & 0 & 0 & 20 \\
\hline 2 & $\begin{array}{c}\text { Anak mampu menjaga barangnya } \\
\text { maupun milik oranglain. }\end{array}$ & 10 & 50 & 7 & 35 & 3 & 15 & 0 & 0 & 20 \\
\hline 3 & $\begin{array}{c}\text { Anak mengakui dan meminta } \\
\text { maaf bila melakukan kesalahan. }\end{array}$ & 13 & 65 & 4 & 20 & 2 & 10 & 1 & 0,5 & 20 \\
\hline 4 & $\begin{array}{c}\text { Anak mampu merawat barang } \\
\text { milik sendiri. }\end{array}$ & 9 & 45 & 6 & 30 & 4 & 20 & 1 & 0,5 & 20 \\
\hline
\end{tabular}




\begin{tabular}{|l|l|l|l|l|} 
Jumlah Rata-rata Persen & 50 & 33,75 & 13,75 & 0,25 \\
\hline
\end{tabular}

Sumber: Obervasi dilakukan pada tanggal 10 Agustus 2021

Keterangan:

BB : Belum Berkembang

MB : Mulai Berkembangan

CB : Cukup Berkembang

BSH : Berkembang Sesuai Harap an

Bedasarkan data observasi di atas maka dapat dijabarkan bahwasanya anak usia 7-8 tahun yang berada di RW 12, Kelurahan Paie Nan Tigo Kecamatan Koto Tangah, kurang memiliki tanggungjawab belajar dalam pelaksanaan proses pembelajaran dari rumah, hal ini disebabkan karena anak didik merasa dengan adanya belajar dari rumah mengganggu waktu bermain mereka dan juga berdasarkan gambaran tabel di atas anak yang melaksanakan pembelajaran dari rumah memiliki perilaku tanggungjawab belajar yang rendah terhadap proses pembelajaran dari rumah.

Melati, Setiawati, \& Solfema (2018), mengemukakan bahwa perhatian orangtua sangatlah memmengaruhi keberhasilan anak sewaktu belajar. Dikarenakan begitu bermanfaat perhatian orangtua tersebut, sehingga sewaktu merawat dan memerhatikan anak dianjurkan untuk menyesuiakan perkembangannya. Anak usia dini sangat rentan sekali untuk berbuat kesalahan dan tidak mengerti sama sekali tentang suatu tanggungjawab tertentu. Maka orangtua dari sianak lah kemudian yang berkewajiban untuk mengarahkan, membimbing dan mengingatkan anaknya sendiri supaya anaknya mampu bertanggungjawab. Reynold dalam Nuraeni (2018), menyatakan bahwasanya apabila orangtua mengerti dan memahami bahwa anak mudah untuk berbuar kesalahan maka ia akan memberitahu anaknya akan kesalahan yang sudah dilakukannya tersebut dan mencarikan alternatif yang seharusnya dilakukan oleh anak. maka tindakan tersebut secara tidak langsung akan menanamkan karakter tanggungjawab pada anak secara kuat.

Menurut Nuraeni (2018), perilaku bertanggungjawab ialah tindakan yang menunjukkan sikap yang bisa bekerja dengan sendiri. Bisa disimpulkan bahwasanya tanggungjawab ialah kesadaran manusia akan perilaku ataupun perbuatanya yang disengaja ataupun tidak. Dalam melakukan peningkatan tanggungjawab anak dilaksanakan melalui memberi kegiatan berupa tugas serta kepercayaan bahwasanya anak dapat menyelesaikan dengan baik. Setiap orang memiliki tanggungjawab sejak usia dini hingga usia dewasa dilihat dari tingkatan usia tanggungjawab yang dimiliki tidak sama.

Tanggungjawab untuk usia dini cenderung sederhana dari pada tanggungjawab orang dewasa. Namun, tanggungjawab pada dasarnya tidaklah memandang batas umur, karena setiap tindakan pasti terdapat sesuatu yang mesti dipertanggungjawabkan. Dari tindakan-tindakan tersebut maka setiap individu harusnya bertanggungjawab kepada diri sendiri, keluarga, serta masyarakat. Menurut Nuraeni (2018), seorang anak yang memiliki bentuk tanggungjawab ataupun selfresponsibility maka akan mencapai keberhasilan dimasa yang akan datang.

Didasarkan hal tersebut, peneliti tertarik meneliti mengenai "Hubungan Antara Perhatian Orang Tua dengan Perkembangan Karakter Tanggungjawab Belajar Anak Usia 7-8 Tahun di RW 12 Kelurahan Pasie Nan Tigo."

\section{METODE}

Berdasarkan fenomena-fenomena yang ada di latar belakang masalah, maka bahwa penelitian ini menggunakan pendekatan kuantitatif korelasional. Penelitian korelasi yaitu jenis penelitian yang dimanfaatkan untuk menguji keterakitan, hubungan dan seberapa kekuatan hubungan antar variabel tersebut (Sugiyono, 2016). Populasi penelitian ini yaitu keseluruhan orangtua dari anak usia 7-8 tahun di RW 12, Kelurahan Pasie Nan Tigo yang berjumlah 30 orang dan peneliti mengambil $80 \%$ dari populasi sehingga sampelnya sebanyak 24 orang dengan teknik sampel random sampling. Pada teknik pengumpulan data penelitian, peneliti menggunakan angket atau kuesioner. Kemudian teknik analisis datanya memakai rumus persentase dan korelasi spearman rho. 
1. Untuk menggambarkan tingkat perhatian orang tua dan perkembangan karakter tanggungjawab belajar anak usia dini, dengan rumus persentase berikut:

$$
\mathrm{P}=\frac{F}{N} \mathrm{X} 100 \%
$$

Keterangan:

$\mathrm{P}=$ persentase

$\mathrm{f}=$ Frekwensi jawaban

$\mathrm{N}=$ Juml ah responden

2. Untuk mengetahui hubungan antara variabel $\mathrm{x}$ dan $\mathrm{y}$ menggunakan perhitungan statistik rhank order

$$
\text { rumus : } r h o=1-\frac{6 \sum D^{2}}{N\left(N^{2}-1\right)}
$$

Ketrangan:

Rho $=$ Angka indeks korelasi tata jenjang .

$\mathrm{D}=$ Difference, yaitu perbedaan skor pada variabel pertama $\left(\mathrm{R}_{1}\right)$ dengan $\left(\mathrm{R}_{2}\right), \mathrm{D}=\mathrm{R}_{1}-\mathrm{R}_{2}$

$\mathrm{N}=$ Jumlah sampel yang diteliti.

$6 \& 1=$ Bilangan konstan.

\section{HASIL}

Hasil penelitian mengenai hubungan antara perhatian orangtua dengan perkembangan karakter tanggungjawab belajar anak usia 7-8 tahun selama Masa Pandemi di RW 12 Kelurahan Pasie Nan Tigo akan diuraikan pada bagian berikut:

\section{Gambaran Perhatian Orang Tua pada Anak Usia Dini di RW 12 Kelurahan Pasie Nan Tigo}

Data mengenai perhatian orang tua di RW 12 Kelurahan Pasie Nan Tigo, diungkapkan melalui beberapa sub variabel, yakni: 1) Memberi reward atau penghargaan terdiri dari tiga item pernyataan; 2) Memberi bimbingan serta membantu kesulitannya terdiri dari tiga item pernyataan; 3) Memberikan contoh terdiri dari tiga item pertanyaan; dan 4) Memenuhi kebutuhan belajar anak terdiri dari tiga item pernyataan. Secara keseluruhan variabel ini berjumlah sebanyak dua belas (12) item pernyataan yang kemudian disebarkan kepada dua puluh empat (24) orang sebagai responden penelitian. Selengkapnya mengenai data penelitian tersebut, akan digambarkan sebagai berikut.

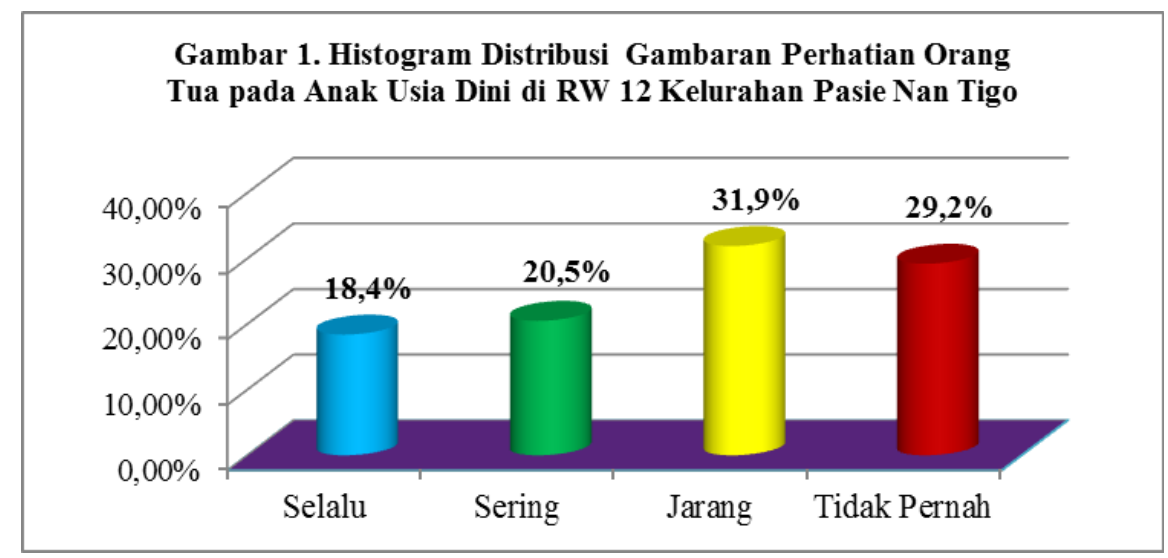

Data gambar 1 tersebut menunjukkan bahwa perhatian orang tua pada anak usia dini di RW 12 Kelurahan Pasie Nan Tigo, reseponden memberi jawaban jarang dengan persentase tertingginya yakni $\mathbf{3 1 , 9 \%}$ dan tidak pernah dengan $\mathbf{2 9 , 2 \%}$. Didasarkan perolehan tersebut, 
disimpulkan bahwa perhatian orangtua pada anak usia dini di RW 12 Kelurahan Pasie Nan Tigo dikategorikan rendah.

\section{Gambaran Perkembangan Karakter Tanggungjawab Belajar Anak Usia 7-8 Tahun Selama Masa Pandemi di RW 12 Kelurahan Pasie Nan Tigo}

Data mengenai perkembangan karakter tanggungjawab belajar anak usia dini selama masa pandemi di RW 12 Kelurahan Pasie Nan Tigo, diungkapkan melalui beberapa sub variabel: 1) Merapikan peralatan ataupun permainan yang telah digunakan terdiri dari tiga item pernyataan; 2) Menjaga barang maupun milik orang lain terdiri dari dua item pernyataan; 3) Mengakui dan meminta maaf jika melakukan kesalahan terdiri dari tiga item pertanyaan; dan 4) Merawat barang milik sendiri terdiri dari tiga item pernyataan. Secara keseluruhan variabel ini sebanyak sebelas (11) item pernyataan yang kemudian disebarkan kepada dua puluh empat (24) orang sebagai responden penelitian. Selengkapnya mengenai data penelitian tersebut, akan digambarkan sebagai berikut.

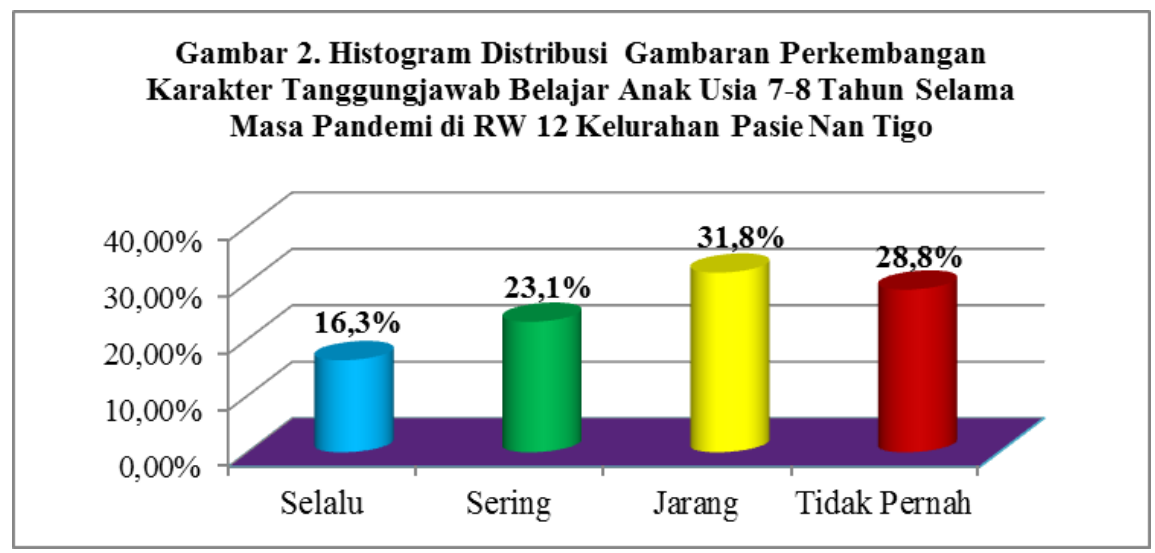

Data gambar 2 tersebut menunjukkan bahwa perkembangan karakter tanggungjawab belajar anak usia 7-8 tahun selama masa pandemi di RW 12 Kelurahan Pasie Nan Tigo, reseponden memberi jawaban mulai berkembang dengan persentase tertingginya yakni $\mathbf{3 1 , 8 \%}$ dan belum berkembang dengan $\mathbf{2 8 , 8 \%}$. Didasarkan perolehan tersebut dapat disimpulkan bahwa perkembangan karakter tanggungjawab belajar anak usia 7-8 tahun selama masa pandemi di RW 12 Kelurahan Pasie Nan Tigo dikategorikan rendah.

Hubungan antara Perhatian Orang Tua dengan Perkembangan Karakter Tanggungjawab Belajar Anak Usia 7-8 Tahun Selama Masa Pandemi di RW 12 Kelurahan Pasie Nan Tigo

Data mengenai hubungan antara perhatian orangtua dengan perkembangan karakter tanggungjawab belajar anak usia 7-8 tahun selama masa pandemi, diuraikan melalui tabel 2 berikut.

Tabel 2. Hubungan antara Perhatian Orang Tua dengan Perkembangan Karakter Tanggungjawab Belajar Anak Usia 7-8 Tahun Selama Masa Pandemi di RW 12 Kelurahan Pasie Nan Tigo

\begin{tabular}{|c|c|c|c|c|c|c|}
\hline \multirow{2}{*}{ Responden } & \multicolumn{2}{|c|}{ Skor } & \multicolumn{2}{c|}{ Rank } & \multirow{2}{*}{$\begin{array}{c}\text { Rx }- \\
\text { Dy }\end{array}$} & $\begin{array}{c}\text { D } \\
\text { Kuadrat }\end{array}$ \\
\cline { 2 - 5 } & $\mathbf{X}$ & $\mathbf{Y}$ & $\mathbf{R x}$ & $\mathbf{R y}$ & $\mathbf{R y}$ & 0,25 \\
\hline 1 & 17 & 16 & 21 & 20,5 & 0,5 & 2,25 \\
\hline 2 & 16 & 14 & 22,5 & 24 & $-1,5$ & 6,25 \\
\hline 3 & 42 & 39 & 5 & 2,5 & 2,5 & 100 \\
\hline 4 & 18 & 36 & 18,5 & 8,5 & 10 & 4 \\
\hline 5 & 18 & 16 & 18,5 & 20,5 & -2 & 90,25 \\
\hline 6 & 19 & 37 & 16 & 6,5 & 9,5 & \\
\hline
\end{tabular}




\begin{tabular}{|c|c|c|c|c|c|c|}
7 & 42 & 36 & 5 & 8,5 & $-3,5$ & 12,25 \\
\hline 8 & 42 & 39 & 5 & 2,5 & 2,5 & 6,25 \\
\hline 9 & 16 & 19 & 22,5 & 12 & 10,5 & 110,25 \\
\hline 10 & 40 & 17 & 8,5 & 16 & $-7,5$ & 56,25 \\
\hline 11 & 44 & 16 & 1 & 20,5 & $-19,5$ & 380,25 \\
\hline 12 & 42 & 39 & 5 & 2,5 & 2,5 & 6,25 \\
\hline 13 & 23 & 21 & 10 & 11 & -1 & 1 \\
\hline 14 & 22 & 22 & 11 & 10 & 1 & 1 \\
\hline 15 & 42 & 37 & 5 & 6,5 & $-1,5$ & 2,25 \\
\hline 16 & 18 & 16 & 18,5 & 20,5 & -2 & 4 \\
\hline 17 & 20 & 17 & 14 & 16 & -2 & 4 \\
\hline 18 & 43 & 38 & 2 & 5 & -3 & 9 \\
\hline 19 & 20 & 17 & 14 & 16 & -2 & 4 \\
\hline 20 & 20 & 18 & 14 & 13,5 & 0,5 & 0,25 \\
\hline 21 & 40 & 39 & 8,5 & 2,5 & 6 & 36 \\
\hline 22 & 21 & 18 & 12 & 13,5 & $-1,5$ & 2,25 \\
\hline 23 & 14 & 16 & 24 & 20,5 & 3,5 & 12,25 \\
\hline 24 & 18 & 16 & 18,5 & 20,5 & -2 & 4 \\
\hline \multicolumn{7}{|c}{ Jumlah } \\
\hline
\end{tabular}

$$
\begin{aligned}
\text { Rho } & =1-\frac{6 \sum D^{2}}{n\left(n^{2}-1\right)} \\
& =1-\frac{6 \times 854,5}{24\left(24^{2}-1\right)} \\
& =1-\frac{5127}{24(576-1)} \\
& =1-\frac{5127}{13800} \\
& =1-0,372 \\
& =0,628
\end{aligned}
$$

Dari analisis data tersebut didapatkan hasil $r$ hitung $=\mathbf{0 , 6 2 8}$. Sedangkan $r$ tabel dengan $N=$ 24 , untuk taraf signifikan 5\% (0,404). Hal tersebut membuktikan bahwa $\mathrm{r}$ hitung $>\mathrm{r}$ tabel. Sehingga demikian dapat disimpulkan bahwa terdapat hubungan signifikan antara perhatian orangtua dengan perkembangan karakter tanggungjawab belajar anak usia 7-8 tahun selama masa pandemi di RW 12 Kelurahan Pasie Nan Tigo. Semakin tinggi perhatian orangtua maka karakter tanggungjawab belajar anak juga semakin tinggi, dan sebaliknya apabila semakin rendah perhatian orangtua maka karakter tanggungjawab belajar anak juga semakin rendah.

\section{Pembahasan}

Pembahasan mengenai hasil penelitian tentang hubungan antara perhatian orang tua dengan perkembangan karakter tanggungjawab belajar anak usia 7-8 tahun selama Masa Pandemi di RW 12 Kelurahan Pasie Nan Tigo akan diuraikan pada bagian berikut:

\section{Gambaran Perhatian Orang Tua di RW 12 Kelurahan Pasie Nan Tigo}

Berdasarkan hasil temuan penelitian menyatakan bahwa perhatian orang tua pada anak usia dini di RW 12 Kelurahan Pasie Nan Tigo dikategorikan rendah, hal tersebut terbukti dari rekapan data yang sudah sudah disebar kepada responden penelitian yang sebagian besar menjawab jarang 
dan tidak pernah pada item pernyataan yang disediakan. Sehingga menunjukkan bahwa perhatian yang diberikan orangtua terhadap anaknya masih rendah.

Perhatian orang tua pada anak usia dini yang diuji pada penelitian ini yaitu: 1) memberi reward atau penghargaan; 2) memberi bimbingan serta membantu kesulitannya; 3) memberikan contoh; dan 4) memenuhi kebutuhan belajar anak. Umumnya semua bentuk perhatian orang tua tersebut belum sepenuhnya dilakukan dengan baik oleh orangtua di RW 12 Kelurahan Pasie Nan Tigo.

Perhatian mempunyai pengertian yang beragam yaitu saling melengkapi antara satu dengan yang lain. perhatian juga dapat di artikan sebagai hubungan erat dengan aktivitas kesadaran jiwa akan sesuatu objek. Perhatian ialah minat ataupun sesuatu perbuatan yang disukai. Jadi perhatian adalah suatu minat maupun beragam aktivitas yang dilakukan yang didasari atas kesukaan dan kesenangan akan aktivitas tersebut. Orang tua ialah ayah dan ibu kandung dari sang anak. Orang tua ialah bagian dari komponen keluarga yang sudah membentuk ikatan perkawinan dan menghasilkan keturunan yang terdiri dari ayahh dan ibu (Maulani \& Bartin, 2021).

Dalam keluarga, anak akan mendapatkan bimbingan guna membina karakter dan wataknya. Anak akan mendapatkan dasar-dasar pendidikan melalui orang tuanya. Oleh karenanya orang tua diharuskan untuk menanam norma dan nilai-nilai yang berlaku di dalam masyarakat kepada diri anak supaya ia bisa terarah secara baik, orang tua juga harus mampu membangun hubungan yang harmonis dengan anak. Hubungan yang harmonis inilah yang kemudian dapat membentuk kondusifnya aktivitas belajar (Safitri, Setiawati, \& Aini, 2018).

Di dalam keluarga, orang tua wajib memberikan perhatian dan melaksanakan perananya sebagai orang tua. Orang tua mempunyai fungsi tersendiri dalam sebuah keluarga. Mengenai fungsi keluarga ialah sebuah perkerjaan ataupun tugas yang perlu dilakukan didalam maupun di luar lingkungan keluarga. Orangtua hendaknya senantiasa selalu mengawasi dan memperhatikan moral dan spiritual anaknya dengan mengajaknya untuk selalu berbuat kebaikan. Perhatian yang diberikan orangtua mampu mempengaruhi perkembangan moral dan tanggungjawab anak. Apabila perhatian yang diberikan orangtua kurang, maka akan terhambatnya perkembangan moral dan tanggungjawab anak tersebut, sehingga anak cenderung berperilaku negatif (Melati et al., 2018).

Perhatian orang tua salah satu bentuk simpati, kasih sayang serta bentuk kepedulian orang tua akan keberadaan anaknya. Selain itu orang tua juga membimbing kegiatan belajar anaknya melalui, penyediaan sarana dan prasarana pembelajaran sebagai pendukung proses pembelajaran bagi anak (Shaumi \& Ismaniar, 2020). Bentuk lain dari kepedulian orang tua terhadap anaknya adalah memberikan fasilitas dan apresiasi pada anak dalam proses belajar.

Perhatian dan peranan orang tua tentang pendidikan anaknya dapat membantu keberhasilan pendidikan anaknya, dimana peran orang tua yakni seperti sebagai pendidik (educator), pendorong (motivator), fasilitator dan sebagai pembimbing anak-anaknya. Di dalam keluarga, orang tua wajib memberikan perhatian dan melaksanakan perananya sebagai orang tua. Orang tua mempunyai fungsi tersendiri dalam sebuah keluarga. Mengenai fungsi keluarga ialah sebuah perkerjaan ataupun tugas yang perlu dilakukan di dalam maupun di luar lingkungan keluarga.

Menurut Ismaniar (2019), fungsi orangtua adalah: fungsi sosialisasi, fungsi afeksi, fungsi edukatif, fungsi protektif, fungsi religius, dan sebagai fungsi ekonomis. Orang tua ialah pendidik yang paling terdekat dengan anak, dan orangtua lah yang bertanggungjawab atas perkembanagan minat belajar seorang anak, dengan perhatian yang di berikan orang tua dapat mempengaruhi minat belajar anak.

Kesimpulannya bahwa perhatian orang tua sangat berperan penting terhadap perkembangan kemampuan dan perilaku tanggungjawab anak usia dini di RW 12 Kelurahan Pasie Nan Tigo. Karakter tanggungjawab akan berkembang dengan baik apabila orangtua mampu memberikan perhatian yang lebih terhadap anak usia dini.

\section{Gambaran Perkembangan Karakter Tanggungjawab Belajar Anak Usia 7-8 Tahun Selama Masa Pandemi di RW 12 Kelurahan Pasie Nan Tigo}


Berdasarkan hasil temuan penelitian menyatakan bahwa perkembangan karakter tanggungjawab belajar anak usia 7-8 tahun selama masa pandemi di RW 12 Kelurahan Pasie Nan Tigo dikategorikan rendah, hal tersebut terbukti dari rekapan data yang sudah sudah disebar kepada responden penelitian yang sebagian besar menjawab jarang dan tidak pernah pada item pernyataan yang disediakan. Sehingga menunjukkan bahwa perkembangan karakter tanggungjawab belajar anak masih rendah.

Perkembangan karakter tanggungjawab belajar anak usia dini yang diuji pada penelitian ini yaitu: 1) Merapikan peralatan ataupun permainan yang sudah dipakai; 2) Menjaga barang sendiri ataupun milik orang lain; 3) Mengakui dan meminta maaf jika melakukan kesalahan; dan 4) Merawat barang milik sendiri. Umumnya semua bentuk karakter tanggungjawab tersebut belum sepenuhnya dilakukan dengan baik oleh anak usia dini di RW 12 Kelurahan Pasie Nan Tigo.

Pagarwati \& Rohman, (2020), mengungkapkan bahwa tanggungjawab ialah usaha seseorang dalam upaya menjaga dirinya maupun orang lain sehingga ia menjadi seseorang yang bisa melaksanakan tugasnya untuk turut aktif dalam kegiatan bermasyarakat sehingga kemudian terbentuklah sebuah tatanan kehidupan yang lebih baik dan layak. Nuraeni (2018), tanggungjawab adalah karakter yang sebaiknya ditanamkan sedari kecil. Hal ini dikarenakan karakter yang berkualitas ialah apabila sudah dibina dan dibentuk sedini mungkin. Karakter tanggungjawab haruslah dimiliki anak supaya ia kelak menjadi pribadi yang bertanggungjawab di masa mendatang. Apabila hal ini gagal ditanamkan sedari dini maka di masa mendatang malah akan menimbulkan permasalahan

Dalam proses menanamkan rasa tanggungjawab pada anak sebenarnya orang tua bisa saja melakukannya tanpa memandang usia dari anaknya. Sebab usia bukanlah menjadi pengahalang dalam menanamkan sikap tanggungjawab pada anak. Setiap anak harus mempunyai sikap tanggungjawab yang disesuaikan dengan kapasitas dan tahap perkembangannya. Bahkan sejak di usia dini, anak sudah mempunyai sebuah dorongan untuk bersikap tanggungjawab. Sikap ini bisa diamati dari kebiasaan anak yang sudah mulai bisa merapikan mainan yang sudah digunakannya, menata kembali buku sekolah yang sudah digunakannya, serta bisa meletakkan barang sesuai dengan tempatnya. Dorongan serta keinginan untuk selalu bersikap tanggungjawab ini sering terhambat karena orang tuanya dalam mengungkapkan perhatian dan kasih sayang pada anaknya yang kurang tepat (Monalisa \& Ismaniar, 2020). Baik itu kepada anaknya masih kecil ataupun kepada anaknya yang sudah besar. Oleh karenanya orang tua disarankan untuk tidak mengambil alih tanggungjawab yang seharusnya dikerjakan oleh anaknya

Cara yang bisa dilakukan dalam menanamkan sikap tanggungjawab kepada anak diungkapkan oleh Melati, Setiawati, \& Solfema (2018), yaitu diantaranya: 1) Ajarkan anak untuk betanggungjawab atas barang-barang miliknya; 2) Ajarkan anak merapikan kamar tidurnya sendiri; 3) Ajari anak untuk berani menerima tanggungjawab diluar rumah; 4) Memberikan pujian pada anak atas tanggungjawabnya; 5) Jadilah manusia yang bertanggungjawab; dan 6) Tentukan batasan yang jelas bagi anak.

Dari uraian tersebut, maka bisa didapatkan kesimpulan bahwasanya penerapan tanggungjawab bisa dilakukan dengan cara-cara sederhana, orang tua tidak perlu memaksa anakya untuk bisa bertanggungjawab layaknya orang dewasa. Anak akan belajar untuk bertanggungjawab dari perbuatan yang dilakukannya sendiri di lingkungan keluarga baru kemudian orang tua memberikan kepercayaan untuk bisa bertanggungjawab di lingkungan sekitarnya.

\section{Hubungan antara Perhatian Orang Tua dengan Perkembangan Karakter Tanggungjawab Belajar Anak Usia 7-8 Tahun Selama Masa Pandemi di RW 12 Kelurahan Pasie Nan Tigo}

Hasil penelitian ini memperlihatkan bahwa terdapat hubungan signifikan antara perhatian orangtua dengan perkembangan karakter tanggungjawab belajar anak usia 7-8 tahun selama masa pandemi di RW 12 Kelurahan Pasie Nan Tigo, dikarenakan $r$ hitung $(\mathbf{0 , 6 2 8})>r$ tabel $(\mathbf{0 , 4 0 4 )}$. Semakin tinggi perhatian orangtua maka karakter tanggungjawab belajar anak juga semakin tinggi, dan sebaliknya apabila semakin rendah perhatian orangtua maka karakter tanggungjawab belajar anak juga semakin rendah. 
Orangtua merupakan pendidik kodrati utama bagi anak, sehingga perhatian yang orangtua berikan terhadap anak sangat besar pengaruhnya bagi masa depan anak. Melati, Setiawati, \& Solfema (2018), menyatakan bahwa orangtua berkewajiban dalam memberikan perhatian kepada anak, diantara perhatian tersebut seperti memberikan bimbingan dengan baik terhadap semua anak-anaknya dengan berdasarkan prinsip kepada akhlak yang mulia, memberikan tanggungjawab sesuai dengan tingkatan usia anak supaya anak bebas memilih segala tindak-tinduknya, memanfaatkan waktu yang tersedia bagi orangtua untuk mengawasi anaknya dengan sadar dan bijaksana seperti menjaga pergaulan anak supaya terhindar dari perbuatan yang melanggar norma yang berlaku dalam lingkungan masyarakat.

Perhatian merupakan pemusatan pikiran pada suatu objek. Kemudian perhatian orangtua kepada anak yaitu bentuk pemberian arahan, nasehat, bimbingan serta pengawasan berupa pemberian kasih sayang dan memenuhi kebutuhan anak sesuai dengan perkembangannya. Menurut Garnika \& Rohiyatun (2021), perhatian orangtua yaitu pemusatan tenaga psikis ataupun sedikit banyaknya kesadaran yang mencakup aktifitas yang dilakukan orangtua kepada anaknya. Bentuk perhatian orangtua dapat berupa pemberian bimbingan. Bimbingan yang diberikan kapada anak sangat penting karena anak masih dalam tahap labil, orangtua harus memberikan nasihat kepada anak ketika perbuatannya tidak sesuai dengan norma. Selain itu orangtua harus mengawasai segala kegiatan anak agar perkembangannya bisa optimal.

Bentuk perhatian orang tua terhadap anaknya bisa berupa menjadi tempat anak berdiskusi, membantu anak mengerjakan pekerjaan rumah yang diberikan oleh guru dan juga memberikan semangat supaya anak dapat belajar dengan baik. Orang tua adalah pendidik yang paling terdekat dengan anak, dan orang tua lah yang bertanggungjawab atas perkembangan belajar seorang anak, dengan perhatian yang diberikan orang tua dapat mempengaruhi tanggungjawab belajar anak.

Tanggungjawab adalah satu kewajiban mengerjakan suatu sikap ataupun perilaku sesuai aturan tertentu, merupakan perilaku yang harus dibangun sejak dini pada anak-anak (Hartati, 2017). Tanggungjawab belajar adalah tindakan atau kewajiban melakukan sesuatu untuk memperoleh suatu perubahan tingkah laku. Sikap tanggungjawab anak bisa ditanamkan melalui hal yang sederhana. Yakni bisa dimulai dari merapikan peralatan yang sudah digunakannya, merapikan kamar dan barang miliknya sendiri.

Orangtua harus menjadi contoh teladan bagi anaknya, hal ini dikarenakan anak butuh juga penguatan yang mampu memotivasinya supaya bisa bertanggungjawab atas tindakannya. Amla, Ismaniar, \& Sunarti (2018), menyatakan anak mulai belajar tanggungjawab ketika ia sudah beranjak usia dua tahun. Anak belajar untuk mulai merapikan permainan, meletakkan barang pada tempatnya, dan mulai membantu tugas orangtua. Istanti (2018), mengungkapkan bahwasanya membiasakan anak belajar bertanggungjawab itu seimbang pentingnya dengan membiasakan anak belajar membaca.

Febrianti \& Solfema (2021), menyatakan bahwa orangtua yang menyisihkan waktunya untuk anaknya, mengatur jadwal supaya bisa masuk dalam lingkungan anak, mengendalikan perbuatan anak, memberikan contoh teladan yang baik, dan memberikan perhatian pada anak mampu memberikan pengaruh terhadap perkembangan karakter anak terutama terhadap karakter tanggungjawab anak. Utami \& Prasetyo (2021), menyatakan bahwa mengajari anak untuk bertanggungjawab tidaklah mudah untuk dilakukan, akan tetapi hal tersebut perlu dilakukan oleh orangtua dikarenakan karakter tanggungjawab sangat diperlukan anak untuk menjalani kehidupannya. Orangtua sebagai pihak utama dalam menanamkan karakter tanggungjawab pada anak maka ia harus memberi contoh beserta teladan yang baik bagi anak dan memperingati serta mengingatkan anak apabila ia lupa dalam mengerjakan sesuatu yang telah diajarkan kepadanya.

Didasarkan uraian tersebut, maka terbukti bahwa terdapat hubungan yang signifikan antara perhatian orangtua dengan perkembangan karakter tanggungjawab belajar anak usia 7-8 tahun selama masa pandemi di RW 12 Kelurahan Pasie Nan Tigo. 


\section{Kesimpulan}

Kesimpulan dari penelitian hubungan antara perhatian orangtua dengan perkembangan karakter tanggungjawab belajar anak usia 7-8 tahun selama masa pandemi di RW 12 Kelurahan Pasie Nan Tigo, yakni: 1) Perhatian orangtua pada anak usia dini di RW 12 Kelurahan Pasie Nan Tigo dikategorikan rendah. Hal tersebut terbukti dari rekapan data yang sudah sudah disebar kepada responden penelitian yang sebagian besar menjawab jarang dan tidak pernah pada item pernyataan yang disediakan. Umumnya orang tua belum konsisten dalam memberikan perhatian kepada anaknya. Sehingga persentase jawaban jarang dan tidak pernah meraih angka tertinggi; 2) Perkembangan karakter tanggungjawab belajar anak usia 7-8 tahun selama masa pandemi di RW 12 Kelurahan Pasie Nan Tigo dikategorikan rendah. Hal ini bisa diamati dari hasil ceklis perkembangan karakter tanggungjawab belajar anak usia dini pada indikator a) merapikan peralatan ataupun permainan yang telah digunakan; b) menjaga barang maupun milik orang lain; c) mengakui dan meminta maaf jika melakukan kesalahan; dan d) merawat barang milik sendiri yakni memperlihatkan persentase mulai berkembang meraih angka tertinggi; dan 3) Hasil pengelohan data membuktikan bahwa terdapat hubungan yang positif dan signifikan antara perhatian orangtua dengan perkembangan karakter tanggungjawab belajar anak usia 7-8 tahun selama masa pandemi di RW 12 Kelurahan Pasie Nan Tigo.

\section{Saran}

Saran dari penulis mengenai penelitian ini ialah: 1) Diharapkan kepada keluarga agar dapat meningkatkan perhatiannya kepada anaknya, hal ini dikarenakan perhatian yang maksimal diberikan oleh orangtua akan mampu menjadikan anak tumbuh dan berkembang dengan optimal sesuai dengan nilai dan norma yang berlaku di masyarakat; dan 2) Diharapkan peneliti selanjutnya dapat menemukan ataupun meneliti variabel lain yang berpengaruh terhadap perkembangan karakter tanggungjawab belajar anak.

\section{Daftar Pustaka}

Agustiningrum, M. D. B., \& Rohidi, T. R. (2020). Strategi Pengembangan Motorik Anak Usia 5-8 Tahun dan Penanaman Karakter Tanggung Jawab Melalui Tari Nawung Sekar. Sentra Cendekia, 1(1), 15-21. Retrieved from http://e-journal.ivet.ac.id/index.php/Jsc/article/download/1189/867

Amla, R., Ismaniar, I., \& Sunarti, V. (2018). Gambaran Cara Orang Tua dalam Membentuk Kebiasan Belajar Menurut Anak di Jorong Alamanda Kenagarian Kinali Pasaman Barat. Spektrum: Jurnal Pendidikan Luar Sekolah (PLS), $1(1), \quad 99$. https://doi.org/10.24036/spektrumpls.v1i1.9513

Aziz, S. (2016). Pendidikan Keluarga: Konsep dan Strategi. Yogyakarta: Gava Media.

Febrianti, W., \& Solfema, S. (2021). The Relationship Between Parents Attention and Early Childhood Discipline at Kampuang Jambak Kelurahan Batipuh Panjang Kota Padang. SPEKTRUM: Jurnal Pendidikan Luar Sekolah (PLS), 9(2), 226. https://doi.org/10.24036/spektrumpls.v9i2.112597

Garnika, E., \& Rohiyatun, B. (2021). Pengaruh Dukungan Orang Tua Terhadap Kedisiplinan Anak Usia Dini. JPIn: Jurnal Pendidik Indonesia, 4(1), 83-89.

Hartati, S. (2017). Perkembangan Belajar pada Anak Usia Dini. Jakarta: Departemen Pendidikan Nasional.

Ismaniar, I. (2019). Optimalisasi Peran Keluarga Dalam Stimulasi Kemampuan Membaca Awal Anak Melalui Pendekatan Environmental Print. E-Tech: Jurnal Ilmiah Teknologi Pendidikan, 6(2), 1-8. Retrieved from http://ejournal.unp.ac.id/index.php/etech/article/view/101459/100590

Ismaniar, I., Jamaris, J., \& Wisroni, W. (2018). Pentingnya Pemahaman Orang Tua tentang Karakteristik Pembelajaran AUD dalam Penerapan Model Environmental Print Berbasis 
Keluarga untuk Meningkatkan Kemampuan Membaca Awal Anak. KOLOKIUM: Jurnal Pendidikan Luar Sekolah, 6(2), 93-100. https://doi.org/10.24036/kolokium-pls.v6i2.9

Istanti, Y. (2018). Peran Orang Tua dalam Mendidik Anak Usia 7-14 Tahun di RT 04 Desa Cinta Karya Kecamatan Plakat Tinggi Kabupaten Musi Banyuasin. Universitas Islam Negeri Raden Fatah.

Latifah; Ismaniar; Sunarti, V. (2018). Gambaran Penanaman Rasa Percaya Diri Anak Usia Dini oleh Guru di Lembaga PAUD Adzkia III Kelurahan Korong Gadang Kecamatan Kuranji Kota Padang. Spektrum: Jurnal Pendidikan Luar Sekolah (PLS), 1(1), 50. https://doi.org/10.24036/spektrumpls.v1i1.9110

Lickona, T. (2016). Mendidik untuk Membentuk Karakter. Jakarta: Bumi Aksara.

Maulani, N. H., \& Bartin, T. (2021). Hubungan Antara Perhatian Orang Tua dengan Minat Belajar Siswa SMP pada Pembelajaran dari Rumah di RW II Kelurahan Parak Gadang Timur Kota Padang. Jurnal Pendidikan Tambusai, 5(1), 333-341. Retrieved from https://jptam.org/index.php/jptam/article/view/953

Melati, P., Setiawati, S., \& Solfema, S. (2018). Hubungan antara Perhatian yang Diberikan Orang Tua dengan Tingkat Perkembangan Moral Anak Usia Dini. KOLOKIUM: Jurnal Pendidikan Luar Sekolah, 6(1), 79-92. https://doi.org/10.24036/kolokium-pls.v6i1.8

Monalisa, M., \& Ismaniar, I. (2020). Hubungan Pengasuhan Anak Dalam Keluarga Yang Menikah Muda Dengan Perkembangan Karakter Tanggung Jawab Pada Anak Usia 5-6 Tahun Di Korong Sungai Pinang, Nagari Kasang, Kecamatan Batang Anai. SPEKTRUM: Jurnal Pendidikan Luar Sekolah (PLS), 8(3), 293. https://doi.org/10.24036/spektrumpls.v8i3.109592

Nuraeni, N. (2018). Pendidikan Karakter pada Anak Usia Dini. Jurnal Paedogy, 3(1), 65-73. Retrieved from https:/ejournal.undikma.ac.id/index.php/pedagogy/article/download/3039/2074

Pagarwati, L. D. A., \& Rohman, A. (2020). Grandparenting Membentuk Karakter Anak Usia Dini di Masa Pandemi Covid-19. Jurnal Obsesi: Jurnal Pendidikan Anak Usia Dini, 5(2), 1229-1239. Retrieved from https://www.obsesi.or.id/index.php/obsesi/article/view/831

Pujiningrum, E., Siswanto, J., \& Sukamto, S. (2021). Pengaruh Perhatian Orang Tua dan Minat Belajar Siswa pada Pembelajaran Daring terhadap Hasil Belajar Matematika Kelas V SD Negeri Mangunrekso 01. Jurnal Inovasi Oembelajaran Di Sekolah, 2(1), 1-11. Retrieved from https://ejournal.pgrikotasemarang.org/index.php/jips/article/download/9/8

Safitri, N., Setiawati, S., \& Aini, W. (2018). Gambaran Penanaman Kemandirian pada Anak Usia Dini oleh Orang Tua dalam Keluarga. Spektrum: Jurnal Pendidikan Luar Sekolah, 6(1), 84-90. Retrieved from ejournal.unp.ac.id/index.php/pnfi/article/view/9005/101621

Shaumi, A. M., \& Ismaniar, I. (2020). The Relationship Between the Family Communication and Talking Early Children at the Pisang Village Kinali Districts Pasaman Barat. SPEKTRUM: Jurnal Pendidikan Luar Sekolah (PLS), 8(4), 515. https://doi.org/10.24036/spektrumpls.v8i4.110145

Sugiyono. (2016). Metode Penelitian Kuantitatif, Kualitatif, dan Kombinasi (Mixed Methods). Bandung: Alfabeta.

Utami, F., \& Prasetyo, I. (2021). Pengasuhan Keluarga terhadap Perkembangan Karakter Disiplin Anak Usia Dini. Jurnal Obsesi: Jurnal Pendidikan Anak Usia Dini, 5(2), 1777-1786. https://doi.org/10.31004/obsesi.v5i2.985 